\title{
Competitiveness of ALS Inhibitors Resistant and Susceptible BIOTYPES OF GREATER BEGGARTICKS (Bidens subalternans) ${ }^{1}$
}

\author{
Competitividade de Biótipos de Picão-Preto (Bidens subalternans) Resistente e Suscetível \\ aos Inibidores da ALS
}

\author{
LAMEGO, F.P. ${ }^{2}$, VIDAL, R.A. ${ }^{2}$ and BURGOS, N.R. ${ }^{3}$
}

\begin{abstract}
The continuous use of ALS-inhibiting herbicides has led to the evolution of herbicide-resistant weeds worldwide. Greater beggarticks is one of the most troublesome weeds found in the soybean production system in Brazil. Recently, a greater beggarticks biotype that is resistant (R) to ALS inhibitors due to $\operatorname{Trp}_{574}$ Leu mutation in the ALS gene was identified. Also, the adaptive traits between susceptible (S) and R to ALS inhibitors biotypes of greater beggarticks were compared. Specifically, we aimed to: (1) evaluate and compare the relative growth rates (RGR) between the biotypes; (2) analyze the seed germination characteristics of $R$ and $S$ biotypes under different temperature conditions; and (3) evaluate their competitive ability in a replacement series study. The experiments were conducted at the University of Arkansas, USA, in 2007 and at Universidade Federal do Rio Grande do Sul (Federal University of Rio Grande do Sul), Brazil, in 2008. Plant proportions for replacement series studies were respectively 100:0, 75:25, 50:50, 25:75 and 0:100, with a total population of 150 plants $\mathrm{m}^{-2}$. There was no difference in RGR between R and S biotypes. The R-biotype germination rate was lower than that of the $\mathrm{S}$ biotype. However, at low temperature conditions $\left(15{ }^{\circ} \mathrm{C}\right)$, the reverse was observed. In general, there is no difference in the competitive ability between $\mathrm{R}$ and $\mathrm{S}$ greater beggarticks biotypes.
\end{abstract}

Keywords: Bidens, fitness, herbicide resistance, replacement series.

RESUMO - O uso contínuo de herbicidas inibidores da ALS tem levado à evolução de plantas daninhas resistentes mundialmente. Picão-preto é uma das mais importantes plantas daninhas no sistema de produção de soja no Brasil. Recentemente, foi identificado um biótipo de picao-preto resistente (R) aos inibidores da ALS devido à mutação $\operatorname{Trp}_{574}$ Leu no gene ALS. Também, foram comparadas características adaptativas entre biótipos de picao-preto suscetivel (S) e R aos inibidores da ALS. Especificamente, os objetivos deste trabalho foram: (1) avaliar e comparar o crescimento relativo (RGR) entre os biótipos; (2) analisar características da germinação das sementes dos biótipos $R$ e S sob diferentes condições de temperatura; e (3) avaliar suas habilidades competitivas em um estudo em série de substituição. Os experimentos foram conduzidos na University of Arkansas, EUA, em 2007 e na Universidade Federal do Rio Grande do Sul, Brasil, em 2008. Para os estudos de série de substituição as proporções de plantas dos biótipos foram, respectivamente: 100:0, 75:25, 50:50, 25:75 e 0:100, com uma população total de 150 plantas $m^{-2}$. Não se verificou diferença no RGR entre os biótipos $R$ e $S$. A taxa de germinação do biótipo $R$ foi menor que a do biótipo $S$. Porém, sob baixas condições de temperatura $\left(15^{\circ} \mathrm{C}\right)$, foi observada a situação oposta. Em geral, não há diferença na habilidade competitiva entre os biótipos $R$ e S de picão-preto.

Palavras-chave: Bidens, valor adaptativo, resistência herbicida, série de substituição.

1 Recebido para publicação em 7.8.2010 e na forma revisada em 6.5.2011.

Parte da tese de doutorado em Fitotecnia pela Universidade Federal do Rio Grande do Sul da primeira autora.

$2 \mathrm{CNPq} /$ Brazil and PPG Fitotecnia, Universidade Federal do Rio Grande do Sul - UFRGS, Av Bento Gonçalves 7712, Caixa Postal 15100, 90001-970 Porto Alegre-RS, Brazil, <fabilamego@yahoo.com.br>; ${ }^{3}$ Professor, University of Arkansas, Fayetteville, AR, USA<nburgos@uark.edu>.

Planta Daninha, Viçosa-MG, v. 29, n. 2, p. 457-464, 2011 


\section{INTRODUCTION}

Greater beggarticks is an annual $\mathrm{C}_{3}$ weed species that belongs to the Asteraceae family (Kissman \& Groth, 1999). It can yield up to 3,000 seeds per plant and is one of the most troublesome weeds in nontransgenic (glyphosate-susceptible) soybean production systems in Brazil (Kissman \& Groth, 1999). Greater beggarticks can cause high economic loss if allowed to compete with the crop (Fleck et al., 2002; Rizzardi et al., 2003). Surveys indicate that ALS-herbicide resistance in greater beggarticks is widespread in Brazil (Vidal et al., 2006). Recently, studies evaluating the cause of ALS resistance in greater beggarticks were conducted and a mutated ALS enzyme was found (Lamego et al., 2009a,b). Different methods of weed management should be used by farmers to avoid the evolution of herbicide resistance. However, when herbicide resistance already occurs, it is necessary to know the biology of $\mathrm{R}$ and $\mathrm{S}$ biotypes to develop an efficient alternative management strategy (López-Ovejero et al., 2007).

Long-term prevention and management of herbicide resistance require adopting practices that reduce selection pressure. Achieving this goal requires an understanding of the evolution and dynamics of resistant populations. Survival and reproductive success combine to determine the relative fitness of a phenotype in a particular environment (Holt $\&$ Thill, 1994; Neve et al., 2009). The relative allocation of resources for survival and reproduction throughout the life cycle of an organism determines its fitness. Survivorship may be further partitioned into success of seed, seedling, and mature plant, which in turn is a function of processes such as germination, dormancy, establishment, growth, and reproduction. Fitness of a particular biotype is also determined in the context of prevailing environmental conditions and other biotypes in that environment. Therefore, both adaptation and competitiveness define fitness (Holt \& Thill, 1994).

Fitness is a combined manifestation of growth characteristics, survival, and production of viable seeds (Holt \& Radosevich, 1983). It seems that being ALS-resistant is not detrimental to the population and many observations to this effect can be found in the literature (Christoffoleti et al., 1997; Park et al., 2004; Crooks et al., 2005; Massinga et al., 2005). However, some results have showed difference in seed germination between ALS-resistant and -susceptible biotypes when submitted to low temperatures (Dyer et al., 1993; Eberlein et al., 1997, 1999). Previous experiments demonstrated that high levels of valine, leucine and isoleucine in the seeds confer advantages for the $\mathrm{R}$ biotype during the germination process at low temperature conditions (Dyer et al., 1993; Eberlein et al., 1997).

A major concern associated to herbicide resistance is that resistant plants may exhibit more fitness than its susceptible counterparts, resulting in a more invasive and noxious weed (Ellstrand, 1999). However, herbicide resistance genes may also result in growth reduction (Radosevich, 1987). In which case, the resistant plants will be at a disadvantage once the herbicide selection pressure is removed. Sibony \& Rubin (2003) showed that ALS-resistant and -susceptible biotypes of redroot pigweed (Amaranthus retroflexus) expressed similar ecological fitness. Also, studies on ALS-resistant Kochia scoparia, downy brome (Bromus tectorum), prostrate pigweed (Amaranthus blitoides), common cocklebur (Xanthium strumarium), common sunflower (Helianthus annuus), and prairie sunflower (Helianthus petiolaris) did not show growth penalty (Christoffoleti et al., 1997; Park et al., 2004; Crooks et al., 2005; Massinga et al., 2005). These indicate that, in the absence of ALS inhibitors, the resistant biotype will remain at a similar frequency in a mixed population of R and S plants (Duff et al., 2009).

In studies on competitive relationships it is important to consider not only the plant density (no. of plants per unit area) but also the proportions of competing plant types. In a replacement series study the total plant density is kept constant, whereas the mixture proportions of two competing species vary (Radosevich, 1987). The yield of the mixtures is compared to the yield of the monoculture of each species. The method is most valuable in assessing the competitive effects of two species at a single total density and determining the relative degrees of intra- and interspecific interference (Radosevich, 1987). 
Protox-susceptible and resistant common waterhemp (Amaranthus rudis) biotypes were equally competitive (Duff et al., 2009). Also, for ACCase-susceptible and - resistant biotypes of Digitaria ciliaris there were no differences in plant development and biomass (LópezOvejero et al., 2007). However, for green pigweed (Amarathus powellii), the $\operatorname{Trp}_{574}$ Leu ALS mutation caused significant pleiotropic effects on the early growth and development of the plants which, in competitive conditions, greatly reduced fitness (Tardif et al., 2006). Also, triazine-resistant weed biotypes with altered target site are almost always less vigorous than susceptible biotypes of the same species (Vaughn, 2003). Therefore, the altered target site mechanism of resistance to triazine herbicides had a fitness cost to the plant.

In another study on ALS-resistant Solanum ptychanthum Dun. harboring a target site mutation, $\mathrm{Ala}_{205} \mathrm{Val}$, there was no difference in competitive abilities between $R$ and $S$ biotypes (Ashigh \& Tardif, 2009). Under optimal light conditions, the $\mathrm{S}$ populations always had higher seed production and fitness than the $\mathrm{R}$ populations. This would likely cause $\mathrm{S}$ individuals to dominate in the absence of herbicide selection pressure. If the $\operatorname{Trp}_{574}$ Leu mutation in greater beggarticks ALS (Lamego et al., 2009) causes a penalty in plant growth, development, or reproduction, this makes it easier for farmers to eliminate the resistant population from nontransgenic soybean fields.

The general objective of this research was to compare the adaptive traits between susceptible and resistant to ALS-inhibiting herbicides biotypes of greater beggarticks.

\section{MATERIAL AND METHODS}

In 2005, seeds from $\mathrm{R}$ and $\mathrm{S}$ to ALSinhibiting herbicides biotypes of greater beggarticks were collected from soybean fields in Brazil. Resistant seedlings were treated with chlorimuron (Classic 25DF, Dupont) at 20 g a.i. ha ${ }^{-1}$ plus $0.25 \%$ (v/v) AG-98 nonionic surfactant when the plants were at the 2to4-leaf stage to confirm the resistance. Chlorimuron was applied using a laboratory sprayer equipped with a flat fan nozzle delivering $200 \mathrm{~L} \mathrm{ha}^{-1}$ at $200 \mathrm{kPa}$.
Experiments on relative growth rate: Two experiments were conducted in the greenhouse, in 2007 (experiment 1) and 2008 (experiment 2), at the University of Arkansas, USA, and Universidade Federal do Rio Grande do Sul (Federal University of Rio Grande do Sul), Brazil, respectively. For experiment 1, day and night temperatures were 30 and $25^{\circ} \mathrm{C}$, respectively, with $4-\mathrm{h}$ days. $\mathrm{S}$ and $\mathrm{R}$ greater beggarticks biotypes seeds were sown in plastic flats filled with a commercial soil mixture (Sunshine Mix) and placed in the greenhouse. Seedlings from both biotypes were transplanted to 4-L plastic pots, one plant per pot, arranged in a randomized complete block design with four replications. Twenty days after transplanting, pots were placed outside of the greenhouse. The pots were rotated to new positions every week to minimize environmental variability and border effects within the experiment. In experiment 2 , day and night temperatures were 25 and $20^{\circ} \mathrm{C}$, respectively, with a 12 -h day period. The procedure used was the same as that in experiment 1. For both experiments, plant height was measured and plants were sampled for dry biomass every week until the onset of flowering. At each sampling, plants were removed from the pots, and roots were gently and thoroughly washed with water. Plants were then sectioned into roots and shoots, oven dried for $48 \mathrm{~h}$ at $60{ }^{\circ} \mathrm{C}$ and weighed.

Experiments on seed germination: two seed germination experiments were conducted in 2007 and 2008, at the University of Arkansas, USA, and Universidade Federal do Rio Grande do Sul (Federal University of Rio Grande do Sul), Brazil, respectively. Six-cm-diam Petri dishes were used in a completely randomized design with four replications. For experiment 1, 25 seeds of $\mathrm{R}$ and $\mathrm{S}$ biotypes were germinated in Petri dishes in a germination chamber under controlled conditions $\left(28 / 25^{\circ} \mathrm{C}\right.$ day/ night temperature, with a $12-\mathrm{h}$ photoperiod). Each Petri dish represented an experimental unit. The experiment was repeated. Germinated seeds were counted every two days for a period of two weeks. For experiment 2, Petri dishes were arranged in a 2 ( $\mathrm{S}$ and $\mathrm{R}$ biotype seeds) by 6 (days of counting: 2, 4, 7, 9 , 11 and 14) by 5 (temperatures: 15, 20, 25, 30 and $35{ }^{\circ} \mathrm{C}$ ) factorial in a randomized complete block design with four replications. 
Samples of R and $\mathrm{S}$ biotype seeds were sent to the Laboratório de Análises Micotoxicológicas (Laboratory of Mycotoxicological Analysis) in the city of Santa Maria, State of Rio Grande do Sul, Brazil, to quantify the total amino acids using HPLC-LCMS/MS.

Replacement series: two experiments were conducted in the greenhouse, in 2007 and 2008, at the University of Arkansas, USA, and Universidade Federal do Rio Grande do Sul (Federal University of Rio Grande do Sul), Brazil, respectively. Day and night temperatures were 30 and $25^{\circ} \mathrm{C}$, respectively, with a $14-\mathrm{h}$ day period. Pots $(6 \mathrm{~L}, 25.4$ by $30.5 \mathrm{~cm}$ ) filled with a commercial soil mixture (Sunshine Mix) were arranged in a randomized complete block design with four replications. The planting mixture proportions (plants/pot) were 12:0, 9:3, 6:6, 3:9 and 0:12 susceptibleresistant greater beggarticks biotypes. The $\mathrm{S}$ biotype was previously paired in six plant proportions $(2,4,8,16,32$ and 64 plants per pot, equivalent to $25,50,100,200,400$ and 800 plants $\mathrm{m}^{-2}$ ) to determine competitive relationships relative to monoculture for the established proportion of plants. Fortytwo days after emergence, plants were cut at soil surface, oven dried for $48 \mathrm{~h}$ at $60{ }^{\circ} \mathrm{C}$ and weighed. Competitiveness of the species was evaluated based on the relative yield (RY) (Equation 1) of the dry weights of aboveground parts (shoots):

\section{$\mathrm{RY}=\mathrm{wmix} / \mathrm{wmon}$}

[eq. 1]

Relative yield is the ratio between the weight of the species in the mixture (wmix) and the weight of the species in monoculture (wmon). Relative total yield (RYT) is the total RY of the two associated species (Equation 2):

$$
\mathrm{RYT}=\mathrm{RYA}+\mathrm{RYB}
$$

A relative yield total of 1 indicates that species $A$ and $B$ are making demands on the same limiting resources. If RYT is $<1$ it indicates that there is a mutual antagonism between species $A$ and $B$. The relative competitivity index $(\mathrm{RC})$, the relative grouping coefficient $(\mathrm{K})$ and the competitivity (A) were calculated at the $50 \%$ proportion of plants from each competing biotype. $\mathrm{RC}$ represents the relative growth of one biotype compared to its competitor; $\mathrm{K}$ indicates the relative dominance of one biotype over another, and A indicates which biotype is more competitive.

Statistical Analysis: data were subjected to ANOVA, which means they were separated using Fisher's Protected LSD at $\mathrm{P} \leq 0.05$. For relative growth rate experiments, growth curves were generated by the exponential equation (Equation 3) in Sigma Plot:

$$
\mathrm{Y}=\operatorname{aexp}(\mathrm{bX})
$$

Relative growth rates (RGR) were calculated according to Radosevich (1987), Equation 4:

$$
\mathrm{RGR}=\mathrm{dw} / \mathrm{dt}
$$

where $d w$ is the change in dry weight over a given time interval, $d t$. For seed germination experiments, data were analyzed using nonlinear regression, and fitted with a logistic equation (Equation 5), using Sigma Plot:

$$
\mathrm{Y}=\mathrm{a} / 1+\left(\mathrm{X} / \mathrm{X}_{50}\right)^{\mathrm{b}}
$$

The average of germination (MLIT) was determined according to Czabator (1962) apud Ranal \& Santana (2006), Equation 6:

$$
\begin{array}{r}
\text { MLIT }=(\mathrm{G} 1 \mathrm{~T} 1+\ldots+\mathrm{GnTn}) /(\mathrm{G} 1+. .+\mathrm{Gn}) \\
\text { [eq. 6], }
\end{array}
$$

where G1 is the number of germinated seeds on day 1 and $\mathrm{T} 1=$ time in days; germination rate (TG) according to Maguire (1962) apud Ranal \& Santana (2006), Equation 7:

$$
\mathrm{TG}=(\mathrm{G} 1 / \mathrm{T} 1+\ldots+\mathrm{Gn} / \mathrm{Tn}) \quad \text { [eq.7], }
$$

and the germination velocity index (CVG) in percentage, according to Kotowski (1926) apud Ranal \& Santana (2006), Equation 8:

$$
\mathrm{CVG}=100 / \mathrm{MLIT}
$$

To assess the competitiveness of either biotype, the four models for interference as proposed by Harper (1977) were used. These models described the possible outcomes of the interaction of two species when grown in a replacement series arrangement (Radosevich, 1987). The index was calculated based on equations by Cousens \& O’Neill (1993).

\section{RESULTS AND DISCUSSION}

Relative growth rates. An interaction between biotype and growing period $(\mathrm{P}<0.01)$ was 
observed for plant height. At $46 \mathrm{DAE}$, plant height was $71 \mathrm{~cm}$ for S- and $56 \mathrm{~cm}$ for Rbiotype. There were no differences between biotypes in terms of shoot (Figure 1), and total biomass (Figure 2), and the root:shoot ratio (data not shown) at $46 \mathrm{DAE}$. Similar results were observed by Christoffoleti et al. (1997) for ALS-resistant Kochia scoparia biotypes and Vidal \& Trezzi (1999), for ALS-resistant wild poinsettia (Euphorbia heterophylla). Also, López-Ovejero et al. (2007) did not observe differences in plant growth and development between R- and S-biotypes when studying resistance to ACCase inhibitor-herbicides in Digitaria ciliaris.

Fitness studies. In 2007, $\mathrm{S}$ biotype showed $100 \%$ germination in $8 \mathrm{~d}$ of incubation whereas $\mathrm{R}$ biotype needed $14 \mathrm{~d}$ to achieve $90 \%$ germination (Figure 3). In 2008, R and $\mathrm{S}$ biotypes showed differences in MLIT, TG and CVG (Table 1), which supports the observations in 2007. In general, the S biotype germinated faster than the $\mathrm{R}$ biotype. There was no difference in seed weight (Table 1) between $R$ and $\mathrm{S}$ biotype. Because fitness is a combined manifestation of growth characteristics, survival, and production of viable seeds (Holt \& Radosevich, 1983), we can say that the $R$ biotype is as fit as the $\mathrm{S}$ biotype. It seems that being ALS-resistant is not detrimental to this population. Many observations to this effect can be found in the literature (Christoffoleti et al., 1997; Park et al., 2004; Crooks et al., 2005; Massinga et al., 2005).

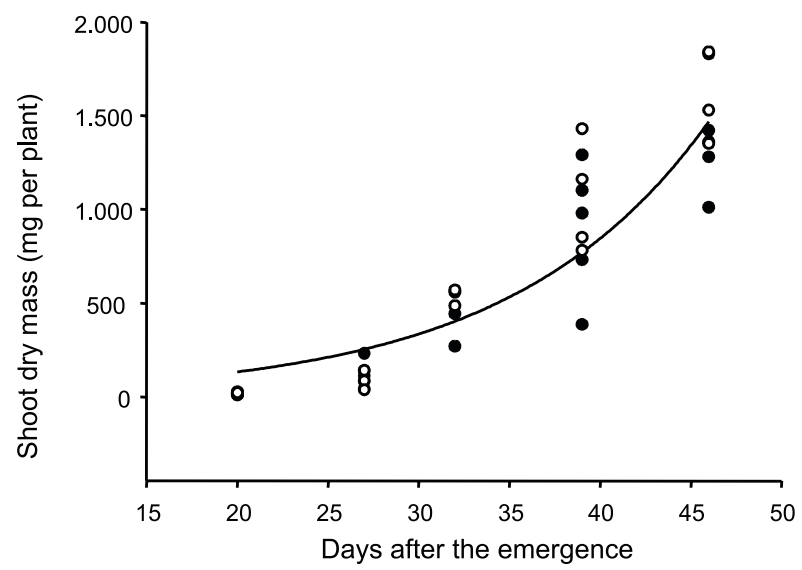

Figure 1 - Shoot dry mass of ALS-resistant and ALS-susceptible greater beggarticks biotypes, University of Arkansas, USA, 2007.
When different temperature conditions were evaluated, $60 \%$ of seeds from the $\mathrm{S}$ biotype germinated in $3 \mathrm{~d}$ at $22.8{ }^{\circ} \mathrm{C}$ (data not shown). At the same temperature conditions, the $\mathrm{R}$

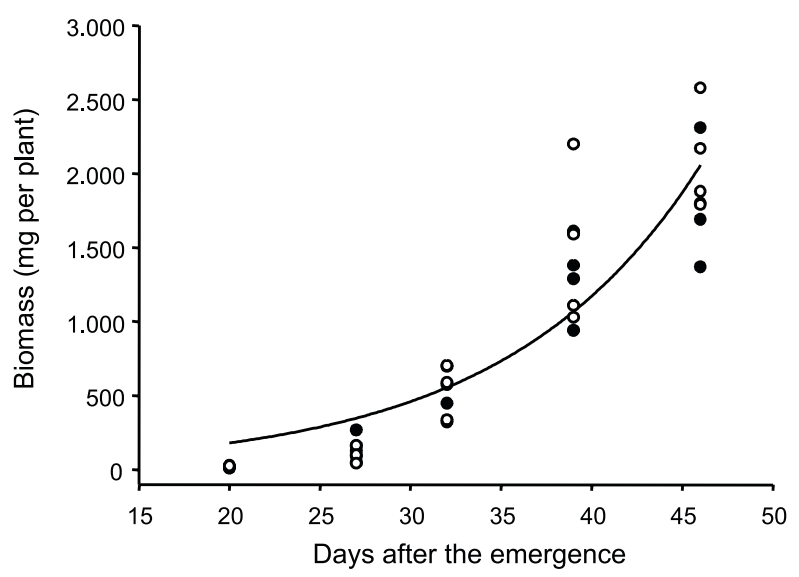

Figure 2 - Biomass of ALS-resistant and ALS-susceptible greater beggarticks biotypes, University of Arkansas, USA, 2007.

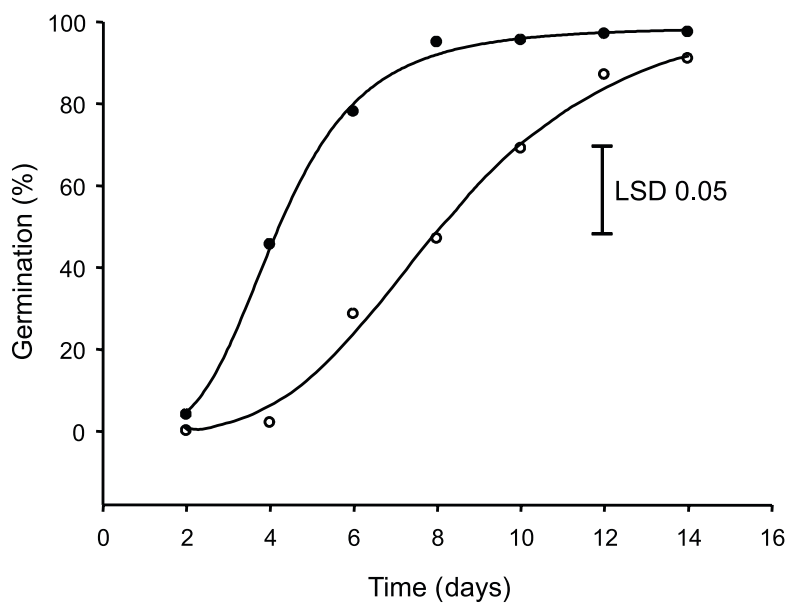

Figure 3 - Percentage of germination of ALS-resistant (o) and ALS-susceptible $(\bullet)$ greater beggarticks biotypes, University of Arkansas, USA, 2007.

Table 1 - The average of germination (MLIT), germination rate (TG), germination velocity index (CVG) and seeds weight of ALS-resistant and ALS-susceptible greater beggarticks biotypes. Federal University of Rio Grande do Sul, Brazil, 2008

\begin{tabular}{|l|l|l|l|l|}
\hline \multicolumn{1}{|c|}{ Biotype } & MLIT & TG & CVG & \\
\hline Susceptible & $5,41^{* 1}{ }^{\prime}$ & $5,03 *$ & $19,29 *$ & $257,25^{\text {ns }}$ \\
\hline Resistant & 8,81 & 2,81 & 11,85 & 271,50 \\
\hline
\end{tabular}

${ }^{1 /}$ Averages followed by asterises in the columns are significantly different $(\mathrm{P} \leq 0.01)$ according to " $\mathrm{t}$ " test; ${ }^{\text {ns }}$ no statistical difference. 
biotype took $5 \mathrm{~d}$ to reach $60 \%$ germination. However, at $15{ }^{\circ} \mathrm{C}$, the $\mathrm{R}$ biotype needed just $4 \mathrm{~d}$ to achieve $60 \%$ germination, whereas the $\mathrm{S}$ biotype needed $5 \mathrm{~d}$ to reach the same germination level. Similar results were observed by Dyer et al. (1993), Eberlein et al. (1997) and Eberlein et al. (1999).

Levels of leucine and isoleucine in the seed were $10 \%$ higher for the $\mathrm{R}$ greater beggarticks biotype than for the $\mathrm{S}$ biotype. Previous experiments demonstrated that high levels of valine, leucine and isoleucine in the seeds confer advantages to the $\mathrm{R}$ biotype during the germination process at low temperature conditions (Dyer et al., 1993; Eberlein et al., 1997). According to Eberlein et al. (1997), ALS enzyme activity in ALSresistant prickly lettuce was $57 \%$ lower than that of the S biotype. Further, the ALS enzyme from the $\mathrm{R}$ biotype was less sensitive to amino acid regulation, considering that this enzyme is normally feedback-regulated by its amino acid products. The reduced response to feedback regulation was correlated to higher valine, leucine and isoleucine concentrations in the ALS-R seeds. High levels of isoleucine and valine, both required for DNA synthesis, can stimulate cellular division and accelerate seedling growth of the ALS-R biotype at low temperatures (Eberlein et al., 1999).

Replacement series study. There was no difference in the competitive abilities between the R and $\mathrm{S}$ biotypes except at the 50:50 (R:S) proportion where the $\mathrm{S}$ biotype showed RY reduction for MSPA (Figure 4). Likewise, there was no difference in RYT between biotypes (Table 2). However, the line representing RYT at the 50:50 plant density proportion was $<1$. If RYT is inferior to 1 (corresponding to a concave line), that is an indication that the two plant types are competing for the same resources and one or both are negatively affected by this competition (Radosevich, 1987). The RY curves of $\mathrm{R}$ and $\mathrm{S}$ biotypes intersected to the right of the 50:50 proportion, which also indicates that the RY of S plants was reduced in relation to to the RY of $R$ plants at this proportion. In this case, the $\mathrm{R}$ plants utilized the resources more than the $\mathrm{S}$ plants when competing on a $1: 1$ basis. In a replacement series study comparing ALS-resistant and susceptible biotypes of Solanum ptychanthum no

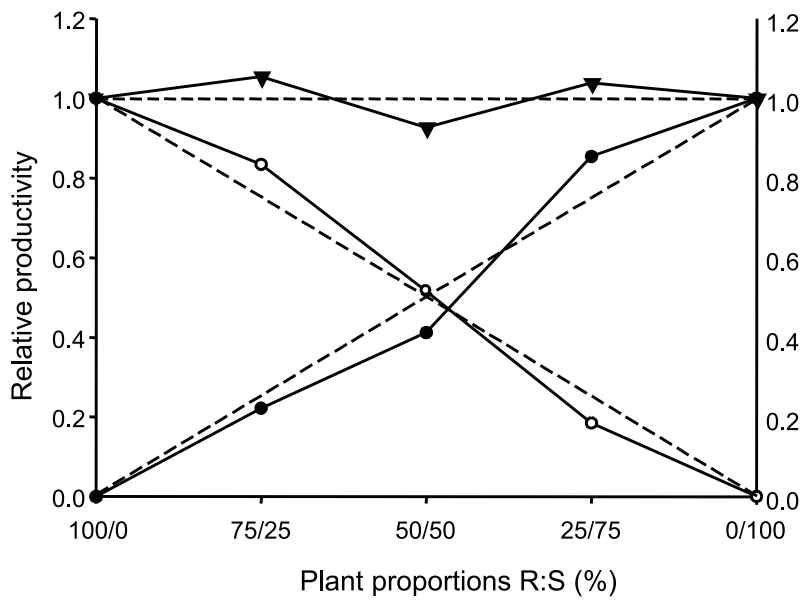

Figure 4 - Relative yield (RY) and total relative yield (RYT) of ALS-resistant and ALS-susceptible greater beggarticks biotypes, University of Arkansas, USA, 2007. (•) and (o) indicates RY for ALS-S and ALS-R and ( $\boldsymbol{\nabla}$ ) indicates RYT.

Table 2 - Relative yield differences and total relative yield of ALS-resistant and ALS-susceptible greater beggarticks biotypes. University of Arkansas, USA, 2007

\begin{tabular}{|l|c|c|c|}
\hline \multirow{2}{*}{ Biotype } & \multicolumn{3}{|c|}{ Plant proportion (resistant:susceptible) } \\
\cline { 2 - 4 } & $75: 25$ & $50: 50$ & $25: 75$ \\
\cline { 2 - 4 } & \multicolumn{3}{|c|}{ Dry shoot mass } \\
\hline Resistant & $0,08( \pm 0,07)^{\text {ns } 1 /}$ & $0,02( \pm 0,02)^{\text {ns }}$ & $-0,07( \pm 0,03)^{\text {ns }}$ \\
\hline Susceptible & $-0,03( \pm 0,03)^{\text {ns }}$ & $-0,09( \pm 0,02)^{*}$ & $-0,10( \pm 0,03)^{\text {ns }}$ \\
\hline Total & $1,05( \pm 0,09)^{\text {ns }}$ & $0,93( \pm 0,02)^{\text {ns }}$ & $1,04( \pm 0,06)^{\text {ns }}$ \\
\hline
\end{tabular}

${ }^{1 /}$ Averages followed by asterises in columns are significantly different $(\mathrm{P} \leq 0.05)$ according to " $\mathrm{t}$ " test; ${ }^{\mathrm{ns}}$ indicates no statistical difference.

difference was observed regarding their competitive ability (Ashigh \& Tardif, 2009).

The biotypes did not show differences for RG and A, which indicates that both had equivalent growth rates. However, the relative grouping indexes showed superior value for the $\mathrm{R}$ biotype, which was a reflection of the dry mass reduction of $\mathrm{S}$ biotype when planted in a similar proportion to the $\mathrm{R}$ plants.

Mutual existence of the biotypes according to the MSPA showed that intra-specific competition was not detrimental to the $R$ biotype (Table 3). The highest MSPA averages were observed when the $\mathrm{R}$ biotype was grown alone or in the same or superior proportions to the S plant populations. 
Table 3 - Interference of ALS-resistant and ALS-susceptible greater beggarticks biotypes $42 \mathrm{~d}$ after emergence. University of Arkansas, USA, 2007

\begin{tabular}{|c|c|c|c|c|c|c|c|}
\hline \multirow{3}{*}{ Biotype } & \multicolumn{5}{|c|}{ Plant proportions (R:S) } & \multirow{3}{*}{ CV (\%) } & \multirow{3}{*}{ Average } \\
\hline & 10100:0(R) & $75: 25$ & $50: 50$ & $25: 75$ & $0: 100(\mathrm{~S})$ & & \\
\hline & \multicolumn{5}{|c|}{ Dry shoot mass } & & \\
\hline Resistant & 1,56 & 1,74 & 1,61 & $1,15^{* 1 /}$ & - & 15,9 & 1,51 \\
\hline Susceptible & - & 1,13 & 1,05 & 1,45 & $1,28^{\mathrm{ns}}$ & 15,2 & 1,21 \\
\hline
\end{tabular}

${ }^{1 /}$ Averages followed by asterises are significantly different $(\mathrm{P} \leq 0.05)$ from the check $(\mathrm{R}$ or $\mathrm{S})$ according to Dunnett's Test; ${ }^{\mathrm{ns}}$ indicates no statistical difference.

In this study, the two evaluated biotypes generally showed the same fitness characteristics, agreeing with previous related experiments. Therefore, managing the $\mathrm{R}$ biotype will be as difficult as managing any greater beggarticks population, even if ALS herbicides are removed from the production system. With the increase of the use of transgenic glyphosate-R soybean in Brazil, ALS-resistant greater beggarticks biotypes have been controlled. However, the adoption of the technology should be done with care to avoid the evolution of greater beggarticks which are also resistant to glyphosate. Horseweeds (Conyza canadensis and Conyza bonariensis) and Italian ryegrass (Lolium multiflorum) are examples of glyphosate resistance evolution (Roman et al., 2004; Moreira et al., 2007; Lamego \& Vidal, 2008; Moreira et al., 2010). Horseweeds, in special, have caused losses in transgenic glyphosate$\mathrm{R}$ soybean fields, and have also forced farmers to use mechanical or manual control. Integrated weed management practices should always be considered by farmers and agronomists working in extension, in order to avoid the evolution of new $R$ populations once the fitness between $R$ and $S$ biotypes has been the same.

\section{ACKNOWLEDGEMENTS}

The authors thank Carlos Eduardo Schaedler from Universidade Federal de Pelotas (Federal University of Pelotas), Brazil, for his assistance in statistical analysis for the Replacement Series studies. The assistance in the greenhouse work at the University of Arkansas by Vinod Shivrain and Marites Sales was highly appreciated. This research was funded by CNPq - Conselho Nacional de
Desenvolvimento Científico e Tecnológico (National Council for Scientific and Technological Development), Brazil and the Weed Physiology Laboratory, CSES, University of Arkansas, USA.

\section{LITERATURE CITED}

ASHIGH, J.; TARDIF, F. J. An amino acid substitution at position 205 of acetohydroxyacid synthase reduces fitness under optimal light in resistant populations of Solanum ptychanthum. Weed Res., v. 49, n. 5, p. 479-489, 2009.

CHRISTOFFOLETI, P. J.; WESTRA, P.; MOORE III, F. Growth analyses of sulfonylurea-resistant and susceptible kochia (Kochia scoparia). Weed Sci., v. 45, n. 5, p. 691-695, 1997.

COUSENS, R.; O’NEILL, M. Density dependence of replacement series experiments. Oikos, v. 66, n. 2, p. 347-352, 1993.

CROOKS, H. L. et al. Vegetative growth and competitiveness of common cocklebur resistant and susceptible to acetolactate synthase-inhibiting herbicides. Cotton Sci., v. 9, n. 4, p. 229-237, 2005.

DUFF, M. G.; AL-KHATIB, K.; PETERSON, D. E. Relative competitiveness of protoporphyrinogen oxidase-resistant commonwaterhemp (Amaranthus rudis). Weed Sci., v. 57, n. 2, p. 169-174, 2009.

DYER, W. E.; CHEE, P. W.; FAY, P. K. Rapid germination of sulfonylurea resistant Kochia scoparia L. accessions is associated with elevated seed levels of branched-chain aminoacids. Weed Sci., v. 41, n. 1, p. 18-22, 1993

EBERLEIN, C. V. et al. Physiological consequences of mutation for ALS-inhibitor resistance. Weed Sci., v. 47, n. 1, p. 383-392, 1999.

EBERLEIN, C. V. et al. Altered acetolactate synthase activity in ALS-inhibitor resistant prickly lettuce (Lactuca serriola). Weed Sci., v. 45, n. 2, p. 212-217, 1997. 
ELLSTRAND, N. C. Gene flow and introgression from domesticated plants into their wild relatives. Ann. Rev. Ecol. Syst., v. 30, p. 539-563, 1999

FLECK, N. G. et al. Densidade e características morfológicas de plantas de picão-preto na previsão de perdas de rendimento de grãos de soja por interferência.

Planta Daninha, v. 20, n. 2, p. 169-179, 2002.

HARPER, J. L. Substitutive experiments. In: HARPER, J. L. Population biology of plants. New York, Academic Press, 1997. p. 255-267.

HOLT, J. S.; RADOSEVICH, S. R. Differential growth of two common groundsel (Senecio vulgaris) biotypes.

Weed Sci., v. 31, n. 2, p. 112-120, 1983

HOLT, J. S.; THILL, D. C. Growth and productivity of resistant plants. In: POWLES, S. B.; HOLTUM, J. A. M. Herbicide resistance in plants. Boca Raton: CRC Press, 1994. p. 299-316.

KISSMAN, K. G; GROTH, D. Picao-preto (Bidens subalternans). In: KISSMAN, K. G;; GROTH, D. Plantas infestantes e nocivas. São Paulo: Basf, 1999. p. 227-234.

LAMEGO, F. P. et al. Molecular basis of resistance to ALSinhibitor herbicides in greater beggarticks. Weed Sci., v. 57, n. 5 , p. $474-481,2009 a$.

LAMEGO, F. P. et al. Cross-resistance of Bidens subalternans to acetolactase synthase (ALS) inhibitors in Brazil. Weed Res., v. 49, n. 6, p. 634-641, 2009 b.

LAMEGO, F. P.; VIDAL, R. A. Resistência ao glyphosate em biótipos de Conyza bonariensis e Conyza canadensis no Estado do Rio Grande do Sul, Brasil. Planta Daninha, v. 26, n. 2, p. 467-471, 2008.

LÓPEZ-OVEJERO, R. F. et al. Crescimento e competitividade de biótipos de capim-colchão resistente e suscetível aos herbicidas inibidores da acetil coenzima A carboxilase. Pesq. Agropec. Bras., v. 42, n. 1, p. 1-8, 2007.

MASSINGA, R. A. et al. Relative fitness of imazamoxresistant common sunflower and prairie sunflower. Weed Sci., v. 53, n. 2, p. 166-174, 2005

MOREIRA, M. S. et al. Herbicidas alternativos para o controle de biótipos de Conyza canadensis e C. bonariensis resistentes ao glyphosate. Planta Daninha, v. 28, n. 1, p. $167-175,2010$.
MOREIRA, M. S. et al. Resistência de Conyza canadensis e C. bonariensis ao herbicida glyphosate. Planta Daninha, v. 25, n. 1, p. $157-164,2007$

NEVE, P.; VILA-AIUB, M.; ROUX, F. Evolutionarythinking in agricultural weed management. New Phytol., v. 184, n. 4, p. 783-793, 2009.

PARK, K. W. et al. Ecological fitness of acetolactate synthase inhibitor-resistant and -susceptible downy brome (Bromus tectorum) biotypes. Weed Sci., v. 52, n. 5, p. 768-773, 2004.

RADOSEVICH, S. R. Methods to study interactions among crops and weeds. Weed Technol., v. 1, n. 3, p. 190-198, 1987.

RANAL, M. A.; SANTANA, D. G. How and why to measure the germination process? Rev. Bras. Bot., v. 29, n. 1, p. 1-11, 2006.

RIZZARDI, M. A.; FLECK, N. G.; AGOSTINETTO, D. Nível de dano econômico como critério para controle de picão-preto em soja. Planta Daninha, v. 21, n. 2, p. $273-282,2003$.

ROMAN, E. S. et al. Resistência de azevém (Lolium multiflorum) ao herbicida glyphosate. Planta Daninha, v. 22, n. 2, p. 301-306, 2004.

SIBONY, M.; RUBIN, B. The ecological fitness of ALSresistant Amaranthus retroflexus and multiple resistant Amaranthus blitoides. Weed Res., v. 43, n. 1, p. 40-47, 2003.

TARDIF, F. J.; RAJCAN, I.; COSTEA, M. A. A. mutation in the herbicide target site acetohydroxyacid synthase produces morphological and structural alterations and reduces fitness in Amaranthus powellii. New Phytol., v. 169, n. 2, p. 251-264, 2006.

VAUGHN, K. C. Herbicide resistance work in the United States Department of Agriculture Agricultural Research Service. Pest Manag. Sci., v. 59, n. 6-7, p. 764-769, 2003.

VIDAL, R. A.; TREZZI, M. M. Desenvolvimento comparativo entre biótipos de leiteira (Euphorbia heterophylla). R. Bras. Agroci., v. 5, n. 1, p. 22-26, 1999.

VIDAL, R. A. et al. Relação entre distância geográfica e variabilidade genética de uma população de Bidens spp. com resistência aos herbicidas inibidores de ALS.

Planta Daninha, v. 24, n. 1, p. 149-155, 2006. 